\title{
Public Perception of the Development of Café Business and its Affect on the Sustainable Conservation District Images : The Case of Braga, Bandung - Indonesia
}

\author{
Bunga Sakina \\ Architecture Department, Faculty of Engineering, \\ Bina Nusantara University, \\ Jakarta, Indonesia 11480 \\ bunga.sakina@binus.ac.id
}

\begin{abstract}
Conservation district has a vital role in supporting a sustainable city. One form of revitalization strategy in conservation district is to incorporate new functions into old buildings, such as café business. The involvement of stakeholders is required to achieve proper implementations of sustainable revitalization, and one of them is the café visitors as the users. The purpose of this study was to find out public perceptions of the development of café business and how café buildings affect the image of Braga conservation district. Several cafés in Braga District of Bandung City were chosen as the object of this research study. This mixed qualitative-quantitative research collected data using the online questionnaire method, unstructured interviews and direct observation. Data analysis was performed quantitatively using distribution analysis. The results of the study showed that the majority of café visitors who are millennial generations visited the café for social interactions. in addition, it was also found that the physical aspects of the café building were also the reason they were attracted to visit the café. Although many cafés arise, public could still feel the image of the Braga conservation district. The café that was considered the most representative of the district's image was a café that retains its original appearance, brings the concept of locality and provide setbacks. The results of this study can be input for the government and the private sector as a direction for the development of sustainable conservation districts.
\end{abstract}

Keywords: conservation district; sustainable; vitalization; café; public perception; conservation district images

\section{INTRODUCTION}

Conservation ditricts reflect the identity and image of a city and can trigger economic growth. In this sense, its role is very important in supporting the formation of a sustainable city (Gedik \& Yildiz, 2016).

Over time, as a result of globalization and urbanization, conservation districts face a decline in quality. In order to maintain and enhance the value of historic areas, various efforts have been made, and one of which is revitalization. In Bandung City Regulation no. 19 of 2009 concerning Management of Regions and Buildings of Cultural Heritage, stated that revitalization is an effort to empower the situation and condition of the area and / or building of cultural heritage for various functions that support its preservation.

One form of revitalization strategy is to incorporate new functions into old buildings (Gedik \& Yildiz, 2016). New functions tend to be adapted to the development of contemporary lifestyle of the community, as well as functions of activities that have economic value, such as boutiques, galleries, and cafés. The existence of this new function can be an additional economic value for the region that supports socio-cultural aspects by attracting various age groups and backgrounds, and indirectly causes some changes to the old physical buildings which then also have an impact on the visualization of buildings in the conservation district.

Braga, located in the city of Bandung, Indonesia, is an example of a district that is experiencing this phenomenon. Braga is a conservation district with historical buildings that has a colonial architectural style. In the 1940s the district was famous as a shopping center. Along with its development, many new commercial functions have emerged, one of which is cafés. To develop this business activity, every café owners applied their own unique concepts.

Nowadays cafés are not only a place to sell drinks or snacks, but cafés have become a contemporary culture. Some literature studies mentioned the theory developed by Ray Oldenburg since 1989 regarding the concept of third place, one of them is café (Waxman, 2006; Woldoff, Lozzi, \& Dilks, 2014). This concept explains that the third place, 
which is a café, is a place other than home and work that is used to create friendships, meet with colleagues to socialize and share information and knowledge. In Woldoff et al. (2014), explained further how the function of the café is moving again, from a place to socialize, to a place to read, work and do productivity. The café has been transformed into a complex multipurpose room, which accommodates a variety of activities.

The success of revitalization cannot be separated from the role of stakeholders, such as café owners and visitors. In the Gedik and Yildiz 's (2016) study it was stated that when user groups were involved in the revitalization process, their awareness of environmental values increased and consequently, they will protect it. Public involvement has a significant contribution to the entire process of sustainable revitalization.

There were several studies that discussed public perceptions of historic areas (Gedik \& Yildiz, 2016; Azhari \& Mohamed, 2012; Haristianti, 2016), but research that specifically addresses the development of cafés in historic areas and their role in the image of the city is still rarely done. Azhari and Mohamed's (2012) study found quite high public awareness of preserving historic buildings. The existence of historic buildings in addition to being a landmark and the main destination of a city, is also effective to protect the beauty of the city's views. A study by Gedik \& Yildiz (2016) found that perceptions from the community as users, play an important role in sustainable revitalization strategies (physical, social, economic, and government)t. The research from Haristianti's (2016), discussed the role of cafés in the development of conservation district in Braga from the perspective of café visitors and the government, but does not discuss community perceptions of the development of the café business in depth.

The purpose of this study was to determine public perceptions of the development of the café business and the role of café buildings on the image of the conservation district. Data obtained through online questionnaire to café users, interviews with café owners and field observations.

The results of this study can be an important input for the government and the private sector as a direction for the development of sustainable conservation districts, especially Braga Street, and similar conservation districts in the future.

\section{METHODS}

In general this research used mixed methods of qualitative-quantitative research (Creswell, 2008). The result was discussed descriptively. This method is used to see the tendency of Bandung people's perception in response to the development of cafés in the Braga conservation district.

The object of this study were four cafés in the Braga District, namely Braga Permai, Braga Punya Cerita, Sugarush, and Myloc. The sample selection of this study used a purposive sampling method (Kumar, 2005). This method was chosen because the four samples were considered to represent the characters of cafés in Braga. Each café sample is considered to have a different character, ranging from the oldest café that can survive with old concepts such as Braga Permai, to very new cafés with very modern-contemporer concepts such as MyLoc.

Primary data were collected using some methods, including an online questionnaire methods, unstructured interviews and direct observation. Meanwhile, the secondary data were gathered from previous studies and literature studies such as related theories that can support this research.

The target respondents for the online questionnaire were café visitors in Braga. The online questionnaire was distributed freely (snowball-non-random-sampling) to the community in Bandung. This method was chosen to see a variety of opinions and responses regarding the existence of the function of cafés in the Braga. The online questionnaire contains questions compiled quantitatively using a structure of mixed questions (open-ended and closed-ended). The structure of the questionnaire items contained respondents' demographic data (i.e. gender, age, and occupation); respondents' responses to the development of café business in Braga (motivation to visit café, intensity of visits, reasons for choosing the café visited and the most visited cafés), and their perceptions to the existence of cafés to the image of the Braga conservation district. Of a total of 65 respondents, the majority of respondents aged ranging from 20 to 35 years, and the rest aged above 35 years.

Interviews and observations were also conducted to strengthen the results of the online questionnaire. Unstructured interviews were conducted directly with the café business owners or resource persons who could represent the owner, because of the limitations to meet directly with the business owner, such as the manager. Questions asked related to their motivation to build a café and their responses of their building design to the Braga conservation district. Observation method was done by taking photos to provide a clearer picture about the condition of the cafés.

Data analysis was performed quantitatively using distribution analysis. This analysis aims to determine the frequency of respondents' dominant and non-dominant responses regarding their behavior when visiting a café as well as their perceptions regarding the existence of a café to the image of Braga Conservation district. 


\subsection{Objects of the Studies}

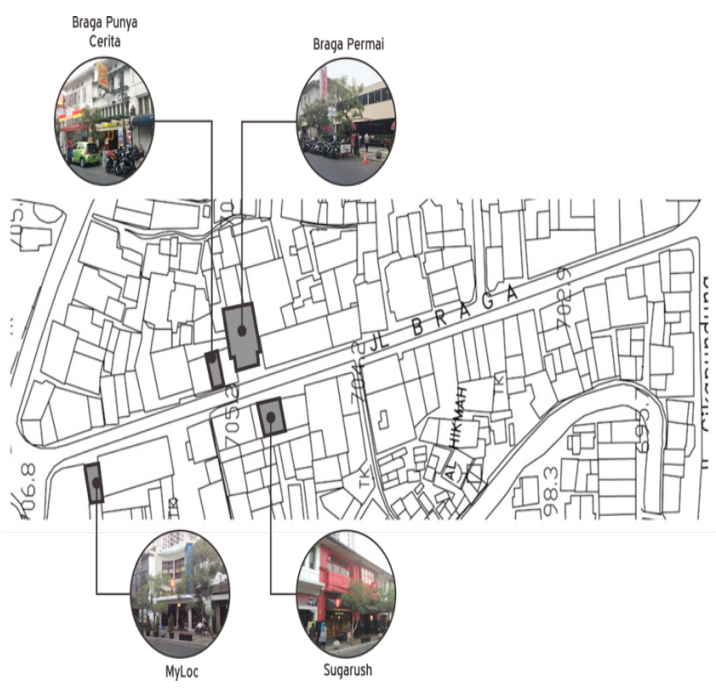

Figure 1 The Studied Cafés in Braga

The study area in Braga conservation district was between ABC Street/ Naripan street and Suniaradja Street/ Lembong Street. While the cafés as the objects of the study were Braga Permai, Braga Punya Cerita, Sugarush, and MyLoc. The location of the cafés in Braga can be seen in Figure 1.

\subsection{Braga Permai Café}

Braga Permai (Figure 2) was one of the oldest businesses in the region, opened in 1918 near the railroad track with the name Maison Bogerijen by L. Van Bogerijen. This café served the government of the Dutch East Indies in Indonesia. In 1923 Braga Permai moved to its current location. This café was passed down and managed by the next generations.

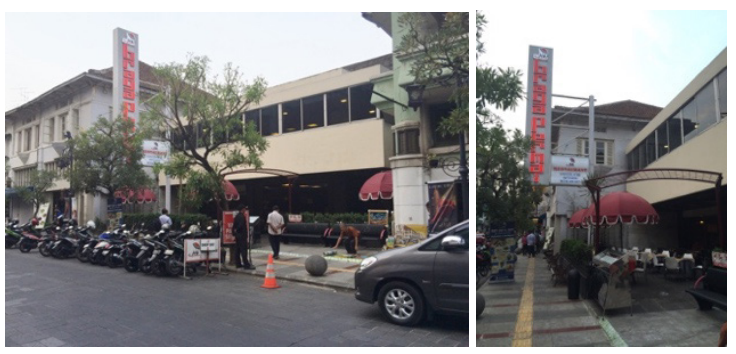

Figure 2 Braga Permai Café

In 1950, when the Japanese entered and fought off the Dutch, the café changed ownership to the natives and changed its name to Braga Permai. When Braga Permai had cought on fire, renovations had to be made. Previously, Braga Permai was only a bakery and sold ice cream, until the ownership went down to the 2 nd generation, the function of the restaurant was added. This café and restaurant has a classy fine dine concept.

\subsection{Braga Punya Cerita Café}

Braga Punya Cerita (Figure 3) was established in April 2015 to coincide with the commemoration of the Asian-African Conference in Bandung. This café carries the theme "Historical of Braga" by displaying the history of Braga from time to time. Previously, this café was a Japanese restaurant called Momigi which was established in 2003. Braga Punya Cerita sells variety of foods and drinks, ranging from coffee, western food, to Indonesian food, in quite affordable prices.

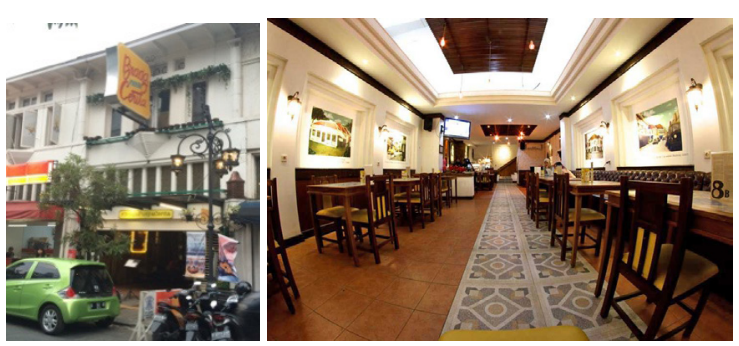

Figure 3 Braga Punya Cerita Café

\subsection{Sugarush Café}

Sugarush (Figure 4) was founded in November 2011. The name Sugarush was taken from the word sugarrush which means the happy reaction of a child when eating sugar or sweet foods.

When this research was conducted, the café had a striking front facade with red paint, matched with the café's logo. However, since the beginning of 2020 this café has a new facade that was merged with the surrounding buildings (figure 4). This café sells variety of foods and drinks, especially snacks and sweets such as various kinds of cakes. This café has an industrial warehouse concept with a vintage interior.

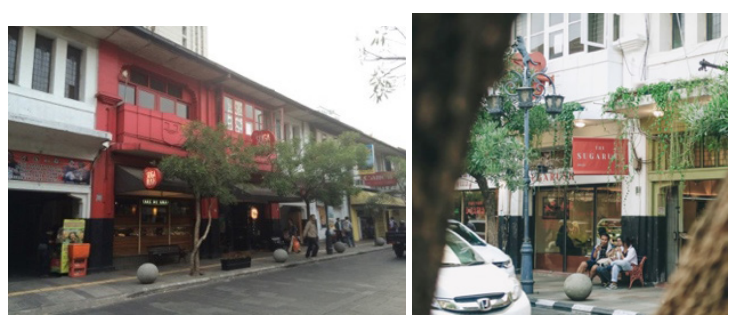

Figure 4 Sugarush then (left) and now (right)

\subsection{MyLoc Café}

MyLoc (Figure 5) was officially opened in July 2015. The word MyLoc was taken from "my location". The café tries to maintain the art deco concept of the original building but adds elements of the $60-70$ s feel to the interior, which was the year of the business owners' generation. This café sells various types of coffee, Western snacks, and also some heavy food.

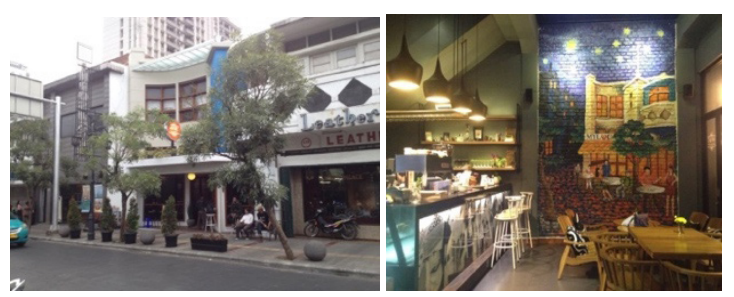

Figure 5 MyLoc Café 


\section{RESULTS AND DISCUSSION}

This section will discuss the results of the analysis of the respondents' demographic data (gender, age, and occupation); respondents' responses to the development of café business in Braga (motivation to visit café, intensity of visits, reasons for choosing the café visited and the most visited cafés), and their perceptions to the existence of cafés to the image of the Braga conservation district.

\subsection{Demographic Data}

Demographic data from the respondents can be seen in Table 1. Of the total 65 respondents, 37 were female respondents (57\%) and 28 were male respondents (43\%). The age range of the respondents varied between the ages of generation X (born between 1965-1979), generation Y (born between 1980-1995), and generation Z (born after 1995) (Dolot, 2018). The majority were generation $Y$ or commonly referred to as millennials by 60 respondents (95\%), followed by generation $X$ by 2 respondents $(3 \%)$ and one respondent from generation $\mathrm{Z}(2 \%)$.

Tabel 1 Respondents' demographic data

\begin{tabular}{ccc}
\hline Characteristics & Frequency & Percentage \\
\hline & Gender \\
\hline Female & 37 & 57.00 \\
Male & 28 & 43.00 \\
\cline { 2 - 3 } Total & 65 & 100.00 \\
\hline Gen X & Age \\
Gen Y & 61 & 3.00 \\
Gen Z & 1 & 95.00 \\
Total & 65 & 2.00 \\
\hline
\end{tabular}

\subsection{Motivations for Visiting Cafés in Braga}

The motivation of visitors to visit cafés in Braga can be seen in Figure 6. There were 6 motivational keywords with a total frequency of 152 keywords. The most chosen keywords were eating/drinking (47 keywords), hanging out (43 keywords), and some mentioned the café as a place of appointment/meeting point ( 31 keywords). In addition there were those who visited the café to work on assignments (11 keywords) and discuss work (19 keywords). There was one other reason; a respondent made the café as an object for news coverage material.

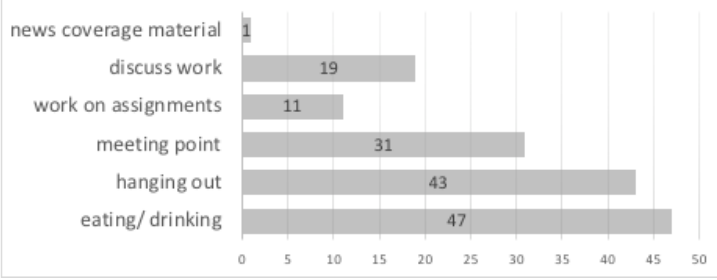

Figure 6 Motivation for Visiting Cafés in Braga

Based on the results of distribution analysis, it can be interpreted that the majority visited the cafés to conduct social interactions such as hanging out and meeting up with friends. These results were similar to research by Farasa and Kusuma (2015), where the main motivation for visiting cafés was to interact with friends.

\subsection{Intensity of Visit to Cafés in Braga}

The respondents were asked to estimate the frequency of visiting cafés in Braga within a month (Figure 7) and the duration in a single visit (Figure 8).

As many as $74 \%$ (48 respondents) came to the café in Braga about 1-2 times a month, 6\% (4 respondents) came up to 3-4 times, and 5\% (3 respondents) came up to more than 4 times. There were also quite a number of respondents who have never been to a café in Braga of 15\% (10 people).

These results indicate that quite a lot of people came to Braga conservation district in Bandung, especially to visit cafés. The addition of their functions for various activities such as cafés, restaurants, hotels, is indeed needed to be able to attract all age groups of people to come and revive the historical area (Gedik \& Yildiz, 2016).

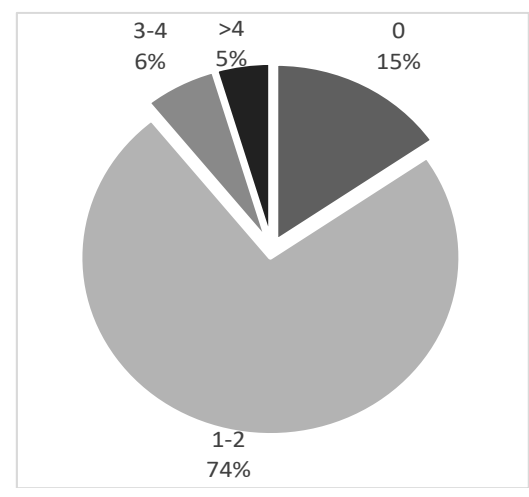

Figure 7 Frequency of Visiting Cafés in Braga within a Month

For the duration of the visit, 51\% spent around $1-2$ hours, $34 \%$ took about $2-3$ hours, $11 \%$ spent more than 3 hours, and only $4 \%$ came in less than 1 hour. This result was likely related to their motivation to visit the café, whether only eating/drinking, to socialize or to do work (Farasa \& Kusuma, 2015).

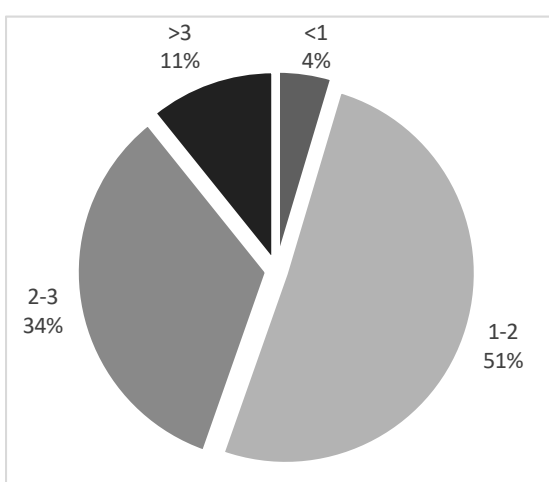

Figure 8 Duration in a Single Visit to Cafés in Braga

\subsection{Reasons to Choose a Café to Visit}

The respondents were asked to select some options concerning the reason they chose a café to visit (Figure 9). There were 8 keywords with a total frequency of 179 
keywords. Most respondents chose "good food/ drinks" (44 keywords), then followed by "affordable prices" (29 respondents), "attractive interior design" (28 respondents), "attractive building appearance" (27 respondents), "conducive atmosphere" ( 24 respondents), "adequate facilities" (16 respondents), "interesting events" (8 respondents), and "interesting promotions" (3 respondents).

Apart from the reasons for enjoying "good food/ drinks" and "affordable prices", quite a number of respondents also chose the physical aspects of the building (interior design and attractive building appearance) as reasons for coming to visit. These results show the importance of architectural aspects in conservation districts These results were in accordance with research findings of Gholitabar et al. (2018) which founded that architecture was one of the main aspects for tourists visiting an historical area.

Research by Farasa and Kusuma (2015) also revealed the role of architecture for the length of stay café visitors spent in cafés. It was founded that female respondents felt at home in cafés that had the appeal of good building designs to express themselves through photographs.

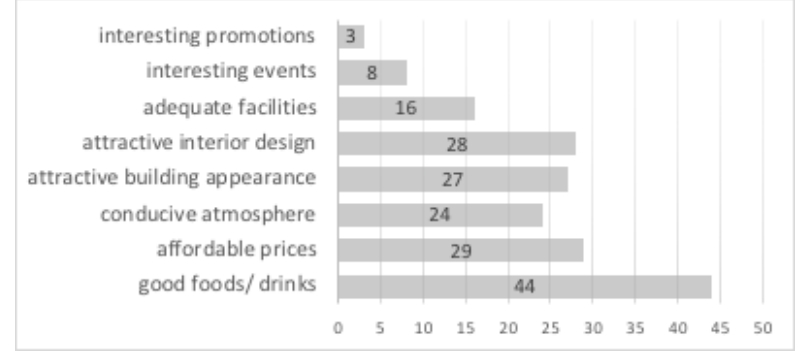

Figure 9 Reasons to Choose a Café to Visit

\subsection{Public Perceptions about the Presence of Cafés on the Image of Braga Conservation District}

The respondents were asked on their opinions, whether with the presence of these cafés, the image of Braga Conservation District could still be perceived (Figure 10).

As many as 58 respondents (84\%) answered that they could still feel the characteristics of the Braga District, while only 11 people (16\%) answered that they could not. Santoni's research (2014) also showed that most buildings in Braga still represented the image of the district. These results indicate that in general the owners of cafés responded well to the status of Braga as a conservation district, by complying with applicable regulations in the district, namely by not changing the building facade from its original conditions.

The majority of the facades in the Braga Region applied the Indische Architectural style (Ratih \& Roychansyah, 2018). This style applies a symmetrical building mass configuration and geometric elements. The material used is monolith material, which tends to be a plaster wall painted in monochrome color and a touch of stained glass.

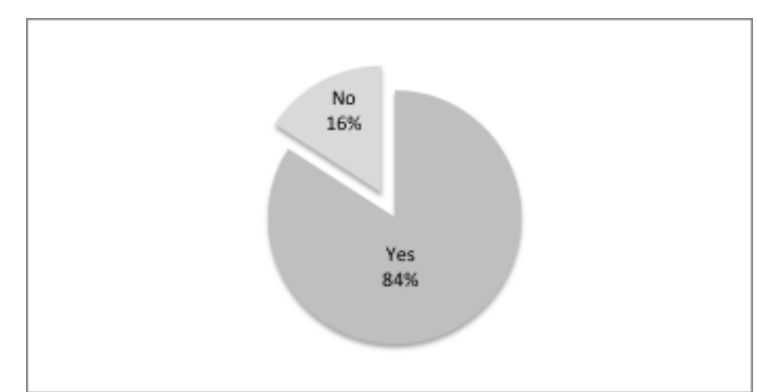

Figure 10 Public Perception on the Presence of Cafés to Braga Image

From the interviews with the owners and resource persons of the cafés, the most basic rule from the government that must be obeyed in Braga district was not to replace the front facade of the buildings. The owners can wanted to make changes, only for building maintenance, for instance, the application of wall paint. In response to this, several cafés then applied the concept through the addition of ornaments such as signage, and/ or explored the interior of the building as their respective identities. Based on the results of Santoni's research (2014) related to physical transformations in Braga, the pattern of changes that often occurs in Braga District is the Level 2 Transformation, where the inner space changes but still maintains the outer appearance which was the creator of Braga's image.

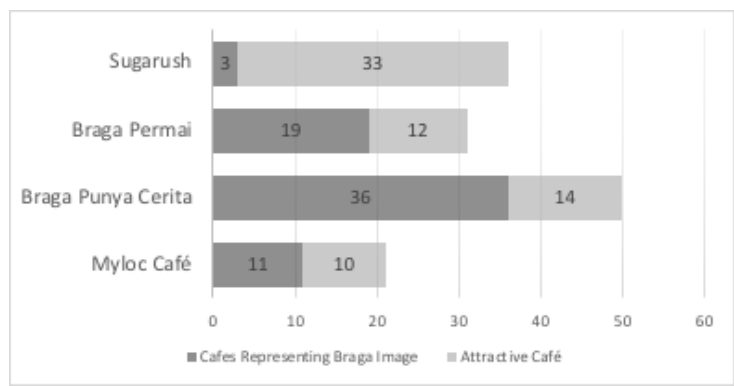

Figure 11 Public Perception on Cafés representing Braga Image and Café Attractiveness

Based on the results of the online questionnaire (Figure 11), it was found that from the four cafés that became the objects of the study, the respondents considered Braga Punya Cerita as the café that best represented the image of Braga conservation district. Thirty six respondents (52\%) thought that the café was still maintained its authenticity. The next café considered to represent the image of the district was Braga Permai with 19 respondents (28\%), followed by Myloc Café with 11 respondents (16\%), and the last was Sugarush with 3 respondents (4\%).

Braga Punya Cerita Café has a unique way to respond to business locations in the conservation district through the concept of locality in the building. This café carries the historical concept of Braga and also the city of Bandung in general, making it an educational café that attracts tourists. On the exterior, this café maintains the original facade of the building. Aside from regulations, the original facade also supports the concept carried by the café, so it only needs to add ornaments as an identity, such as signage with a fairly large size and bright colors. In layout, it was designed with setbacks, the façade that opens to the inside with the impression of "inviting". The interior design was 
incorporating unique furniture that supports vintage themes. These design strategies have proven successful in providing an image of Braga conservation district, as indicated by the results of the online survey.

Sugarush Café has the lowest score for representing the image of Braga District. But inversely proportional to these results, this café was considered to be the most attractive café by respondents. When this research was conducted, the facade of Sugarush had a bright red color, in harmony with the café signage. Not only that, the door and window frames had the same color and even this color was also consistently brought to the interior elements and integrated with industrial concepts. This color concept was thought to be the reason the respondents chose it to be the most interesting café. But unfortunately this also gave a negative response because it reduces the image of Braga conservation district. Sugarush was considered too contrast and not "uniform" with other surrounding buildings. This result was also consistent with the opinion of Mr. Tubagus Adi (interview, 16 November 2015), as an observer of Braga development. Sugarush was seen as very incompatible with the nuances of Braga conservation district, which was dominated by white building facades, and small portions of dark colors. Based on the results of Haristianti's research (2016), the revitalization of the district was considered successful and the image of the area will remain alive when the appearance of the building is left the same as the original appearance.

In early 2020, Sugarush made quite a number of changes to the facade, and the most striking was the color of the facade in front of the building. At present, Sugarush Café chooses to "uniform" itself by using monochrome colors. However, the characteristic of bright red color concept is still maintained in building ornaments, especially signage.

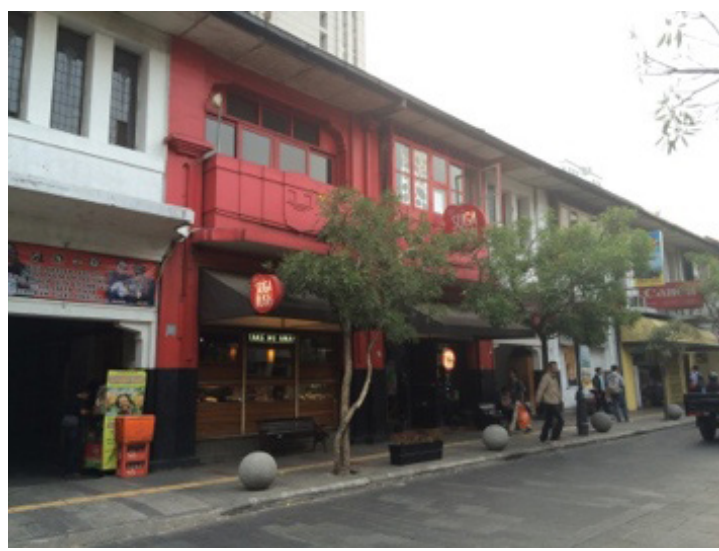

(a)

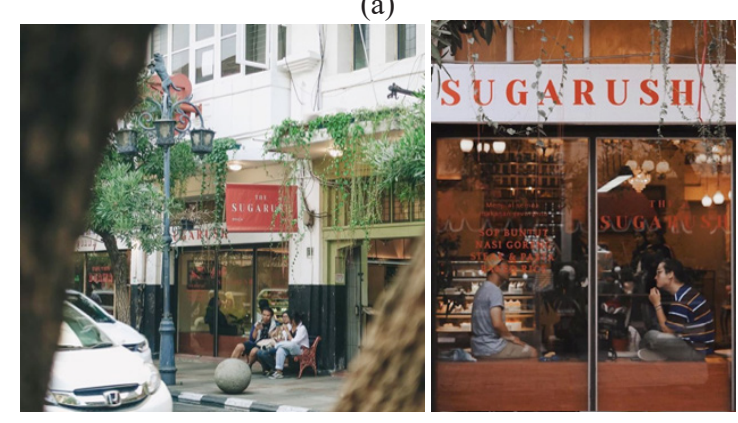

(b)

Figure 12 Sugarush in the past (a) and now (b)
Regarding the layout, the three highest cafés together have front porches or setbacks that gave the impression of European buildings, in accordance with the nuances of colonial buildings inherent in the conservation district. Only Sugarush café doesn't have a setback. Based on a study by Rukmana, et. al. (2017), Building setbacks in historic buildings were aimed at the unity of visual continuity and good urban space scale.

\section{CONCLUSION}

The development of café business in Braga conservation district is in line with the phenomenon that is happening in society today, where the café has become a contemporary culture.

Demographically, based on studies that have been carried out, it was found that the majority of people who visited cafés in Braga conservation were from generation Y or commonly called millennials (born in 1980-1995).

Public responds to the development of the café business in Braga conservation district through data on the motivation to visit the café, the intensity of the visit, and the reasons for choosing the café to be visited.

Their main motivation to visit the café in Braga area was to do social interactions (hang out and meet up). For the intensity of the visit, the majority visited the café in the Braga area about once or twice a week with a duration of one to two hours. Regarding the reason for visiting a café, in addition to enjoying good food/ drinks at affordable prices, the physical aspects of the building (interior design and appearance of the building) were also an attraction for visiting. These results showed the importance of architectural aspects in conservation districts.

The public perceptions of the presence of the café on the image of Braga conservation district obtained positive results, of which the majority can still feel the original atmosphere of the district. These results indicated that in general the café owners responded well to the status of Braga as a conservation district, by not changing the facade of the buildings from its original conditions. The cafés then provide identity through the addition of ornaments such as signage, and explore the concept of building interiors. Having setbacks or front porches also gave nuances of colonial buildings inherent in the conservation districts. The café that was considered the best in representing the image of Braga was Braga Punya Cerita. The café maintained its original appearance, incorporated the concept of locality and applied setback to its interior layout.

Based on the overall results of the study, it can be concluded that the presence of cafés in Braga had become an attraction that can revive the conservation district. From the physical aspect, the application of interesting concepts in the building of these cafés provides an interesting visualization of the district's image. Economically, the café business also indirectly contributed to the economic growth of the city. These café business also supports the socio-cultural aspects by attracting various age of groups 
and backgrounds. Thus, its role is very important to support the formation of sustainable cities.

This perception from the community can be an important input for the government and the private sector as a guide for the development of sustainable conservation districts. Strong collaboration is needed between all stakeholders in order to revitalize conservation districts and create sustainable cities. This research covered a relatively small scope, and therefore, further research needs to be done with more study objects and respondents.

\section{REFERENCES}

Azhari, N. F. N., Mohamed, E. (2012). Public Perception: Heritage Building Conservation in Kuala Lumpur. Procedia - Social and Behavioral Sciences 50 ( 2012 ), $271-279$.

Creswell, J.W. (2008). Research Design: Qualitative, Quantitative, and Mixed Methods Approaches. California: Sage Publications, Inc.

Dolot, A. (2018). The Characteristics of Generation Z. E-mentor, 2(74), 44-50.

Farasa, N. \& Kusuma, H. E. (2015). Faktor-faktor yang Mempengaruhi Kebetahan di Kafe: Perbedaan Preferensi Gender dan Motivasi. Prosiding Temu Ilmiah IPLBI 2015, 029-034.

Gedik, G. S. \& Yildiz D. (2016). Assessing the Role of Users in Sustainable Revitalization of Historic Urban Quarters: The Case of Bursa-Khans District. ITU A|Z, 13(1), 195-208

Gholitabar, S., Alipour, H., Costa, C. M. M. (2018). An Empirical Investigation of Architectural Heritage Management Implications for Tourism: The Case of Portugal. Sustainability 2018, 10(93).

Haristianti, V. (2016) Peran Kafe Terhadap Pembangunan Conservation District Studi Kasus: Kafe di Kawasan Braga, Bandung, Prosiding Temu Ilmiah Ikatan Peneliti Lingkungan Binaan Indonesia (IPLBI) 2016, 129-134.

Kumar, R. (2005). Research Methodology: A Step-By-Step Guide for Beginners. London: Sage Publication.

Ratih, A., Roychansyah, S. (2018). Tipomorfologi Elemen Arsitektur Fasad Jalan Braga, Bandung, Temu Ilmiah Ikatan Peneliti Lingkungan Binaan Indonesia (IPLBI) 7, 020-027.

Rukmana, C. D., Santosa, H., \& Wulandari, L. D., (2017), Tipologi Fasade Bangunan Komersial dI Kawasan Koridor Jalan Soekarno-Hatta Malang, Jurnal Mahasiswa Jurusan Arsitektur Universitas Brawijaya Malang, 5(1).

Santoni. (2014). Transformasi dan Tipologi Bangunan Indoeuropeeschen Architectuur Stijl Kawasan Braga Bandung. E-Journal Graduate Unpar Part D - Architecture Vol. 1, No. 2. 162-177.
Waxman, L. (2006). The Coffee Shop : Social and Physical Factors Influencing Place Attachment. Journal of Interior Design, 31(3.

Woldoff, R. A., Lozzi, D. M., \& Dilks, L. M. (2013). The Social Transformation of Coffee Houses: The Emergence of Chain Establishments and the Private Nature of Usage. International Journal of Social Science Studies. 1(2). 